\title{
PENGARUH KEPEMIMPINAN TRANSFORMASIONAL TERHADAP KINERJA KARYAWAN MELALUI OTONOMI KERJA
}

\author{
Muhammad Alief Ramadhani \\ Universitas Negeri Surabaya \\ Alief.17080574109@mhs.unesa.ac.id \\ Nurul Indawati \\ Universitas Negeri Surabaya \\ Nurulindawati@unesa.ac.id
}

\begin{abstract}
This research aims to explore the effect of transformational leadership on employee performance mediated by job autonomy at CV SKM Indonesia. During this yearly pandemic, job autonomy is applied in CV SKM Indonesia conceived by the work from the home method. Quantitative methods are chosen to process the questionnaire employees filled in-collecting 34 respondents as a total population from multiple divisions in $C V$ SKM Indonesia and using multiple linear regression from SPSS PASW18 software for an analytical tool. This study verifies the positive and significant effect between transformational leadership and employee performance mediated by job autonomy as an intervening variable. This study shows that the practice of transformational leadership from the leader of the company is going well, and employee also has an excellent job autonomy on their self and that is helping them increasing performance to complete their job in the company. The company should let the employee make a monthly evaluation and keep improving their new work system to increase their performance.
\end{abstract}

Keywords: employee performance; job autonomy; transformational leadership.

\section{PENDAHULUAN}

Di zaman modern sekarang ini perkembangan bisnis dan ekonomi akan terus berlangsung. Berkembang atau tidaknya perusahaan salah satunya dipengaruhi oleh faktor internal perusahaan tersebut. Perusahaan dituntut untuk melakukan pengembangan dan mengoptimalkan faktor-faktor internal dikarenakan semakin pesatnya perkembangan bisnis. Hal tersebut penting untuk memantapkan dasar-dasar perusahaan demi keberlangsungan bisnis serta beradaptasi di tengah budaya persaingan (Septyan et al., 2017). Kompetisi global ini mewajibkan kesiapan untuk berubah secara kontinu pada setiap aspek industri. Situasi pandemi covid-19 membuat tuntutan perubahan pada sektor bisnis semakin besar (Asbari et al., 2020). Keberhasilan pemimpin menanggapi tantangan perubahan membutuhkan gaya kepemimpinan yang sesuai dengan tuntutan itu sendiri (Siswatiningsih et al., 2019). Gaya kepemimpinan transformasional merupakan praktik yang sering diterapkan saat ini. Penerapan kepemimpinan transformasional memberikan karyawan rasa percaya, lebih dihargai, patuh serta tanggap kepada pimpinannya. dampaknya karyawan akan mendapatkan motivasi untuk melakukan sesuatu yang lebih dari yang melebihi harapan pemimpin (Yoshi, 2017).

Pandemi COVID-19 membawa kerugian sebab karyawan dan perusahaan mendapatkan banyak pertanyaan dan ketidakpastian. Sebagian orang terkena imbas dari virus ini dengan beragam cara. Salah satunya dengan melanjutkan bekerja di rumah yang akhirnya memunculkan permasalahan baru yaitu stres emosional tinggi yang disebabkan oleh pola dan ruang kerja baru (Diab-Bahman \& AlEnzi, 2020). Otonomi kerja menawarkan kemungkinkan bagi karyawan untuk mendapatkan fleksibilitas dan kebebasan untuk mengatasi beban kerja seefisien mungkin, hingga dapat meminimalkan tekanan, konflik serta kelelahan. Kebebasan tersebut biasanya erat kaitannya dengan penjadwalan, pengembangan inisiatif, prosedur kerja dan kesempatan untuk turut andil kontribusi dalam proses pemilihan keputusan (Handayani et al., 2018). Pandemi ini pula membuat perubahan yang sangat signifikan pada berbagai bidang, salah satunya di bidang ekonomi. Banyak perusahaan mengubah pola kerja mereka salah satunya dengan melakukan metode kerja di rumah (work from home). Hal ini terjadi karena aspek yang paling berpengaruh dalam perusahaan adalah sumber daya 
Muhammad Alief Ramadhani \& Nurul Indawati. Pengaruh Kepemimpinan Transformasional terhadap Kinerja Karyawan melalui Otonomi Kerja

manusianya. Keberhasilan perusahaan dalam melakukan kegiatannya disebabkan oleh kinerja dari karyawan perusahaan tersebut (Hartono \& Rahadi, 2021). Kontinuitas perusahaan dalam meningkatkan kinerja karyawannya diperlukan karena setiap Sumber Daya Manusia (SDM) erat kaitannya pada kemampuan menyusun rencana, mengorganisir, melaksanakan dan mengendalikan beragam strategi dalam upaya untuk pencapaian visi, misi serta tujuan dari perusahaan. Human Resources Development (HRD) dapat memanfaatkan berbagai komponen yang dirasa efektif untuk melakukan peningkatan kinerja pada karyawan mereka (Cahyandani, 2021).

Beberapa penelitian sebelumnya menunjukkan bahwa terdapat pengaruh signifikan positif dari kepemimpinan transformasional terhadap kinerja (Siti, 2017 dan Randy et al., 2019). Aqmarina et al. (2016) menunjukkan hubungan negatif antara kepemimpinan transformasional terhadap kinerja. Nurdin \& Rohendi (2016) dan Nurhuda et al. (2019) menunjukkan bahwa kepemimpinan transformasional tidak berpengaruh terhadap kinerja. Jankelová et al. (2020) menyatakan adanya pengaruh positif antara kepemimpinan transformasional dan otonomi kerja. Herwita \& Irma (2017) menunjukkan adanya hubungan positif signifikan antara otonomi kerja terhadap kinerja, sedangkan Karimikia \& Joseph (2019) menunjukkan bahwa otonomi kerja berpengaruh negatif signifikan terhadap kinerja.

Tujuan dari dilakukannya penelitian ini adalah untuk menunjukkan dampak dari penerapan kepemimpinan transformasional terhadap kinerja karyawan melalui otonomi kerja pada karyawan di CV SKM Indonesia. Perusahaan ini adalah perusahaan jasa yang bergerak pada bidang desain visual, grafis serta pengembangan website dengan target market yang menyasar industri mekanikal, elektrikal, sipil maupun keuangan (SKM Indonesia, 2018). Berdasar hasil wawancara dengan pemilik, saat ini keadaan perusahaan yang bergerak pada sektor jasa desain grafis dan website ini berubah cukup signifikan dikarenakan adanya pandemi. Kepemimpinan transformasional pada CV. SKM Indonesia ini ditunjukkan dari tindakan cepat supervisor yang mengedepankan monitoring secara personal untuk lebih mendekatkan diri kepada karyawan. Selain itu tak jarang pula supervisor langsung membimbing karyawan yang mengalami kendala melalui pertemuan online. Semua hal tersebut dilakukan pimpinan perusahaan melalui arahan supervisor untuk tetap memunculkan rasa percaya dan saling memiliki baik antara karyawan dengan pimpinan maupun karyawan terhadap perusahaan serta sebagai langkah untuk beradaptasi dengan keadaan. Kebijakan pemerintah yang menganjurkan perusahaan melakukan metode kerja dari rumah ternyata dirasa karyawan memberi mereka banyak kemudahan seperti jam kerja yang lebih fleksibel serta dapat mengatur sendiri metode apa yang cocok bagi mereka dalam menyelesaikan pekerjaan mereka. Sebagai respon pada hal tersebut, perusahaan juga memberikan dukungan dengan membuat skema kerja daring melalui pembuatan website yang dapat memudahkan karyawan untuk melakukan absensi, update dari pengerjaan mereka serta dapat menjadwal hari aktif kerja mereka. Namun adanya sistem baru yang mendukung karyawan untuk melakukan pekerjaan secara mandiri di rumah masing-masing ini ternyata masih dirasa kurang optimal oleh HRD pada kinerja karyawan. Hal tersebut disampaikan oleh pihak HRD karena merasa bahwa sistem kerja tersebut masih tergolong baru dan masih perlu dikembangkan. Berdasarkan fenomena tersebut, penelitian ini bertujuan untuk menemukan pengaruh kepemimpinan transformasional terhadap kinerja dimediasi oleh otonomi kerja pada CV. SKM Indonesia.

\section{KAJIAN PUSTAKA DAN PENGEMBANGAN HIPOTESIS}

\section{Kepemimpinan Transformasional}

Kepemimpinan transformasional adalah kemampuan individu dalam menanamkan inspirasi kepada karyawan, mengakomodir kepentingan mereka serta sedemikian rupa dapat memiliki pengaruh kuat yang mendasar di hati karyawan lain (Nurdin \& Rohendi, 2016). Kepemimpinan transformasional bukan sekadar ditujukan untuk mencapai keberhasilan untuk meraih sebuah tujuan dengan membawa pengaruh bagi pengikutnya, lebih dari itu untuk melakukan perubahan sikap dan perilaku sesuai dengan nilai dasar mereka melalui pengembangan potensi. Hasil pengembangan yang didapatkan para karyawan nantinya akan menumbuhkan kepercayaan diri untuk terus melakukan perubahan meskipun terdapat resiko bahwa ia sendiri mungkin terkena dampak dari perubahan itu (Randy et al., 2019). 
Penelitian ini menggunakan indikator kepemimpinan transformasional dari Bass \& Avolio (1990) yaitu: (1) karismatik adalah komponen emosional dalam kepemimpinan yang biasanya mendeskripsikan kekuatan dari pemimpin mampu memberikan dampak yang hebat bagi pengikutnya. (2) motivasi yang menginspirasi adalah kepemimpinan yang menginspirasi dan memotivasi pengikut untuk meraih tujuan yang sebelumnya nampak mustahil untuk berhasil. Disini, pemimpin meningkatkan ekspektasi pengikut dan menginspirasinya dengan berkomunikasi secara percaya diri bahwa organisasi mampu mencapai tujuan bersama. (3) stimulasi intelektual adalah pemimpin mendorong kecerdasan pengikutnya dengan menciptakan kewaspadaan terhadap masalah dan penyelesaian masalah karena karyawan diikut sertakan dalam proses penyelesaian masalah, maka karyawan termotivasi untuk mampu menyelesaikan permasalahan yang ada. (4) konsiderasi individu yaitu pemimpin dalam penerapan konsiderasi individu memberikan perhatian secara individu dan berorientasikan mentoring terhadap pengikut. Tujuan yang ingin diraih adalah coaching dan konseling untuk pengikut, menjaga kontak bersama-sama dan membantu pengikut untuk aktualisasi diri. (Widyawati, 2021).

\section{Otonomi Kerja}

Otonomi kerja adalah situasi ketika sebuah pekerjaan mampu menumbuhkan rasa bebas yang bertanggung jawab, kebijaksanaan serta kemandirian dalam pengaturan jadwal kerja serta penentuan prosedur yang harus digunakan (Aprilia \& Prasetyo, 2019). Lebih jauh lagi memberikan otonomi kerja ini akan berdampak pada peningkatan kebebasan untuk melakukan inovasi yang mampu menumbuhkan perilaku kerja yang inovatif lewat ide dan gagasan dalam pekerjaan ketika karyawan dihadapkan pada kondisi tertekan (Ardy \& Fajrianthi, 2019). Tiga indikator dari Huda \& Bahri (2017) dalam otonomi kerja yaitu: metode kerja, penjadwalan kerja, dan kriteria kerja. Metode kerja merupakan kemampuan seseorang menentukan metode apa yang digunakan dalam menyelesaikan suatu pekerjaan. Penjadwalan kerja merupakan kemampuan seseorang mengatur skema dalam penyelesaian tugas. Kriteria kerja merupakan kemampuan seseorang dalam penyediaan sumber daya yang dibutuhkan untuk evaluasi.

\section{Kinerja Karyawan}

Kinerja merupakan pencapaian hasil dari karyawan selama kurun waktu tertentu berdasarkan pada tugas serta tanggung jawabnya dan berfokus pada tujuan organisasinya (Setiawan, 2015). Kinerja adalah aktivitas yang dilakukan seseorang dengan tujuan untuk mencapai target yang telah ditetapkan (Nazwirman, 2019). Hasil kerja yang dicapai secara kuantitas oleh seorang karyawan berdasarkan tanggung jawab yang dibebankan institusi atau organisasi dalam pelaksanaan tugasnya, serta tugas tersebut diselesaikan sesuai dengan target dari organisasinya. Pada dasarnya, kinerja didefinisikan sebagai pencapaian prestasi atau hasil kerja seseorang. Lebih dari itu, kinerja adalah akhir dari pekerjaan dan kegiatan yang dilakukan oleh seseorang sebagai upaya tercapainya suatu tujuan (Rulysca, 2020). Sehubungan dengan capaian kerja pegawai, di dalamnya banyak timbul permasalahan pada internal perusahaan salah satunya adalah belum cukup optimalnya kinerja pegawai. Hal ini dapat dilihat dari rendahnya tingkat capaian kerja pegawai dengan target yang sudah ditetapkan (Sari \& Hadijah, 2016).

\section{Hubungan antar Variabel}

Siti (2017) melakukan studi pada dinas penanaman modal, menunjukkan bahwa kepemimpinan transformasional memiliki pengaruh signifikan positif terhadap kinerja. Artinya semakin tinggi penggunaan kepemimpinan transformasional di dalam perusahaan mampu meningkatkan kinerja dari karyawan. Aqmarina et al. (2016) menunjukkan hasil kepemimpinan transformasional memiliki pengaruh negatif terhadap kinerja karyawan hotel Gajahmada Graha Malang. Diketahui bahwa fenomena ini dikarenakan kepuasan karyawan pada pekerjaan belum terpenuhi, jika kepuasan kerja karyawan seperti membuat komunikasi yang baik dan mendekatkan relasi antara pemimpin dan karyawan, membimbing dan melakukan pengarahan, tidak terpenuhi maka kinerja karyawan akan menurun. Namun Nurhuda et al. (2019) menyatakan bahwa kepemimpinan transformasional tidak memengaruhi kinerja secara signifikan, sehingga untuk meningkatkan kinerja karyawan lebih baik memberikan semangat kepada karyawan rumah sakit secara langsung daripada menerapkan pola kepemimpinan transformasional. 
Muhammad Alief Ramadhani \& Nurul Indawati. Pengaruh Kepemimpinan Transformasional terhadap Kinerja Karyawan melalui Otonomi Kerja

H1: Kepemimpinan transformasional berpengaruh positif signifikan terhadap kinerja.

Gözükara \& Şimşek (2015) mengukur pengaruh kepemimpinan transformasional pada work engagement melalui otonomi kerja sebagai variabel mediasi pada perguruan tinggi non-profit di Turki menunjukkan bahwa otonomi kerja menunjukkan bahwa otonomi kerja mampu secara signifikan positif memediasi hubungan antara kepemimpinan transformasional terhadap work engagement. Penelitian ini juga menyatakan bahwa otonomi kerja menjadi mediator penuh bagi kepemimpinan transformasional yang berarti bahwa keberadaannya menjadi hal penting dalam penerapan metode kepemimpinan transformasional pada tempat tersebut. Jankelová et al. (2020) meneliti tentang bagaimana cara mendukung variabel kepemimpinan transformasional agar menemukan kecocokan dengan kinerja bagi perusahaan argikultur menggunakan variabel kepemimpinan transformasional dan kepuasan kerja yang berperan sebagai mediator. Hasilnya, baik kepemimpinan transformasional dan kepuasan kerja berpengaruh positif ketika menjadi mediator antara kepemimpinan transformasional dengan kinerja bisnis. Hal menariknya adalah kepemimpinan transformasional tidak memiliki efek positif pada kinerja bisnis jika hanya berdiri sendiri dan faktor lain dibutuhkan untuk memunculkan pengaruh positif. Otonomi kerja dan kepuasan kerja mampu mengubah pengaruh negatif kepemimpinan transformasional menjadi pengaruh positif. Alshamsi et al. (2020) mengukur hubungan kepemimpinan transformasional terhadap komitmen organisasi melalui otonomi kerja sebagai variabel moderasi juga menyatakan bahwa otonomi kerja mampu secara signifikan memengaruhi hubungan antara kepemimpinan transformasional terhadap komitmen organisasi sebesar 64 persen.

H2: Kepemimpinan transformasional berpengaruh positif signifikan terhadap otonomi kerja.

Herwita \& Irma (2017) menunjukkan bahwa otonomi berpengaruh secara signifikan positif terhadap kinerja karyawan ketika diberikan variabel kejelasan tujuan organisasi sebagai variabel mediasi pada PT.PLN wilayah Aceh. Lebih rinci, Muecke (2019) melakukan penelitian meta-analisis terkait bagaimana otonomi kerja memengaruhi kinerja. Menggunakan total 319 studi dengan total responden sebanyak 151134 orang menunjukkan hasil keseluruhan yang menunjukkan bahwa otonomi kerja membimbing kearah kinerja karyawan yang lebih baik karena selain meningkatkan motivasi kerja juga menurunkan ketegangan mental. Namun, Karimikia \& Joseph (2019) yang juga menggunakan meta-analisis menunjukkan bahwa digunakannya teknologi informasi dan telekomunikasi membawa pengaruh negatif bagi hasil kerja karyawan dan secara mengejutkan otonomi kerja sebagai variabel mediasi yang menambah dampak buruk dari pengaruh negatif tersebut.

H3: Otonomi Kerja berpengaruh positif signifikan terhadap kinerja.

Ditemukan pengaruh dan hubungan positif antara variabel kepemimpinan kinerja terhadap kinerja (Randy et al., 2019), kepemimpinan transformasional terhadap otonomi kerja (Gözükara \& Şimşek, 2015), dan otonomi kerja terhadap kinerja (Muecke, 2019). Di sisi lain otonomi kerja juga digunakan sebagai variabel intervening baik pada kepemimpinan transformasional (Alshamsi et al., 2020) maupun kinerja (Karimikia \& Joseph, 2019).

H4: Otonomi kerja dapat memediasi pengaruh antara kepemimpinan transformasional terhadap kinerja.

\section{METODE PENELITIAN}

Penelitian ini bertujuan untuk menganalisis pengaruh kepemimpinan transformasional terhadap kinerja karyawan melalui otonomi kerja sebagai variabel mediasi. Menggunakan metode kuantitatif dengan sumber data primer dari hasil obervasi langsung pada objek penelitian dan data sekunder yang berasal dari sumber literasi sebagai pelengkap. Pengumpulan data tersebut dilakukan memakai metode observasi, wawancara, dan kuesioner. Studi kasus pada pengkajian ini dilakukan di CV.SKM Indonesia. Populasi dalam penelitian ini adalah 34 karyawan kantor yang seluruhnya dijadikan sampel penelitian. Pada penelitian yang dilakukan pengambilan sampel tersebut menggunakan metode 
sampling jenuh. Penelitian ini memilih metode sampel jenuh dikarenakan jumlah populasi terlalu kecil sehingga dimasukkan keseluruhan karyawan menjadi sampel penelitian. Skala likert dipilih untuk metode pengukuran. Data diuji validitas dan reliablitas untuk mengetahui tiap item pernyataan yang digunakan valid dan dapat mewakili variabel yang dipilih. Uji asumsi klasik mencakup yang pertama, uji normalitas, uji multikolinieritas, dan uji heteroskedastisitas. Menentukan pengaruh mediasi, dilakukan metode analisis jalur dan uji sobel. Fungsi analisis jalur adalah menghasilkan koefisien yang dapat digunakan untuk melihat pengaruh langsung dan tidak langsung pada variabelvariabel dalam penelitian. Angka koefisien keluaran dari SPSS dapat menunjukkan seberapa besar pengaruh langsung sedangkan pengaruh tidak langsung diuji melalui penghitungan dengan cara perkalian antar koefisien. Metode yang digunakan untuk menunjukkan pengaruh mediasi adalah uji sobel. Uji sobel dilakukan dengan dua tahapan, pertama metode hitung standar error dari koefisien indirect effect pada rumus (1).

$\mathrm{Sp} 2 \mathrm{p} 3=\sqrt{p 3^{2} S p 2^{2}+p^{2} S p 3^{2}+S p 2^{2} S p 3^{2}}$

Berdasar pada hasil hitung Sp2p3, selanjutnya untuk melihat pengaruh mediasi dilakukan pengujian nilai t statistik menggunakan rumus (2).

$\mathrm{t}=\frac{p 2 p 3}{S p 2 p 3}$

Hasil dari t hitung ini kemudian dilakukan perbandingan dengan nilai $t$ tabel. Jika nilai t hitung menunjukkan angka yang lebih besar dari nilai t tabel, kemudian dapat dibuat bahwa terdapat pengaruh mediasi yang signifikan. Keseluruhan data diolah menggunakan program SPSS PASW18.

\section{HASIL DAN PEMBAHASAN}

\section{Hasil Uji Validitas}

Data yang diuji dikatakan valid apabila $r$ hitung lebih besar daripada $r$ tabel sebesar 0,339 . Hasil validasi variabel kepemimpinan transformasional sebanyak 7 poin pernyataan, semua pernyataan terbukti valid. Hasil uji validasi variabel kinerja sebanyak 10 poin pernyataan, semua terbukti valid. Hail uji validasi variabel Otonomi kerja terdapat 10 poin pernyataan yang valid.

\section{Hasil Uji Reliabilitas}

Hasil uji reliabilitas ditunjukkan pada nilai Cronbach's Alpha. jika nilai tersebut > 0,60 maka keseluruhan item diperbolehkan penggunaannya sebagai alat ukur atau bisa dikatakan konsisten. Nilai Cronbach's Alpha yang didapatkan setelah uji reliabilitas untuk variabel $\mathrm{X}$ adalah 0,790 , nilai variabel $\mathrm{Y}$ adalah 0,696 dan nilai untuk variabel $\mathrm{Z}$ adalah 0,813.

\section{Hasil Uji Asumsi Klasik}

Tabel 1.

UJI ASUMSI KLASIK

\begin{tabular}{cccc}
\hline \multirow{2}{*}{ Variabel } & Normalitas & \multicolumn{2}{c}{ Multikolineritas } \\
\cline { 2 - 4 } & Sig. & Tolerance & VIF \\
Kepemimpinan &, 697 & & \\
Transformasional & &, 600 & 1,666 \\
Otonomi Kerja & &, 600 & 1,666 \\
Dependent Variable: Kinerja Karyawan & & \\
\hline Sumber: Output SPSS PASW18 (Data diolah) &
\end{tabular}


Muhammad Alief Ramadhani \& Nurul Indawati. Pengaruh Kepemimpinan Transformasional terhadap Kinerja Karyawan melalui Otonomi Kerja

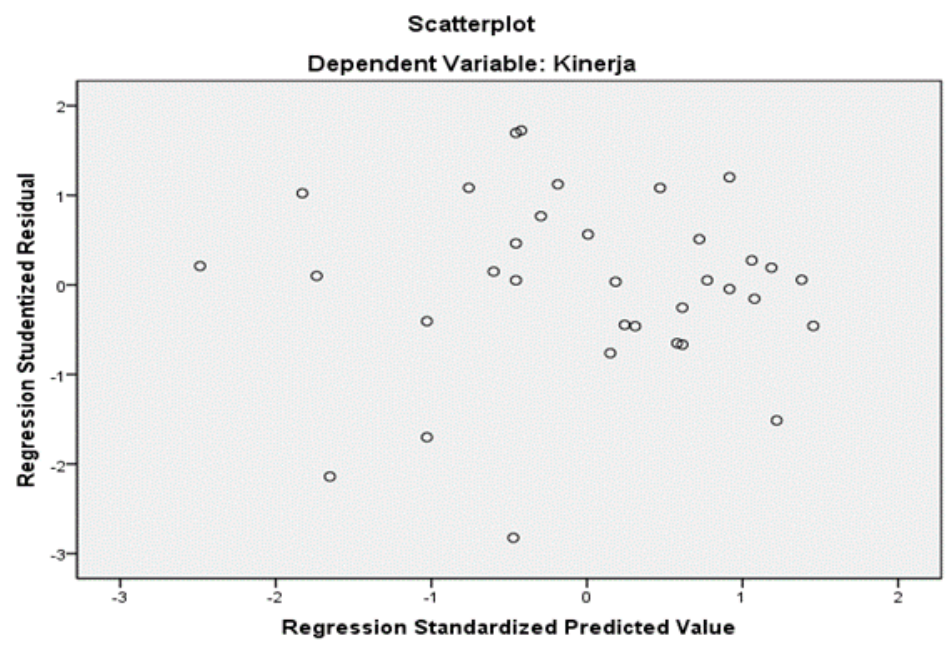

Sumber: Output SPSS PASW18 (Data diolah)

Gambar 2. OUTPUT SCATERPLOTS

Hasil uji normalitas dilakukan dengan metode Kolmogorov-smirnov (KS) ditunjukkan pada tabel 1. memeroleh signfikansi 0,679 atau >0,05. Dari hasil tersebut, dapat dinyatakan data terdistribusi normal. Uji multikolinieritas menunjukkan hasil nilai tolerance $>0,1$ yaitu 0,600 dan nilai VIF yang didapatkan sebesar 1,666 atau < 10. Berdasarkan hasil tersebut, tidak terdapat multikolinierita pada data yang diuji. Uji heteroskedastisitas yang menggunakan output Scatterplots pada gambar 1 menunjukkan titik - titik data tidak berkumpul pada satu area, menyebar di sekitar angka 0 , dan tidak ada pola yang terbentuk. Hal ini berarti bahwa tidak terjadi heteroskedastitas pada data yang diuji.

\section{Hasil Uji Hipotesis}

Uji hipotesis yang dilakukan dengan dua tahapan yaitu analisis regresi sederhana $(\mathrm{H} 1, \mathrm{H} 2, \mathrm{H} 3)$ serta analisis jalur dan uji sobel (H4). Hasil uji determinasi $\left(\mathrm{R}^{2}\right)$ sebesar 0,497 atau $49,7 \%$ yang berarti kemampuan yang dimiliki model dalam menjelaskan variabel kepemimpinan transformasional dan otonomi kerja untuk menjelaskan variabel dependen sebesar 49,7\% sedangkan 50,3\% dijelaskan oleh sebab lain diluar model yang tidak diteliti.

Berdasarkan hasil uji regresi linier berganda dapat ditunjukkan persamaan (3) dan (4).

$Y=\alpha+\beta 1 \mathrm{X} 2+\beta 2 \mathrm{X} 2+\beta n \mathrm{X} n+e$

Kinerja $=13,676+0,332 \times 1-0,359 \times 2+e$

Jika nilai koefisien regresi variabel kepemimpinan transformasional 0 atau otonomi kerja 0 , maka terjadi kenaikan kinerja sebesar 13,676. Jika nilai koefisien regresi, yaitu 0,332 dari variabel kepemimpinan transformasional kemudian diasumsikan dengan pernyataan apabila terjadi pengingkatan senilai 1 pada variabel kinerja maka terjadi kenaikan senilai 0,332 dari nilai variabel kepemipinan transformasional. Dari hasil koefisien yang bernilai positif dapat dinyatakan terdapat hubungan positif dari hubungan kepemimpinan transformasional dengan kinerja. Begitu juga ketika nilai koefisien regresi variabel otonomi kerja yaitu 0,359 kemudian dapat diasumsikan bila terjadi peningkatan senilai 1 dari variabel otonomi kerja maka terjadi kenaikan senilai 0,359 dari nilai variabel kinerja. Dari hasil koefisien yang bernilai positif dapat dinyatakan terdapat hubungan otonomi kerja dengan kinerja.

Tabel 2. hasil uji t secara parsial terdapat pengaruh signifikan positif antara variabel kepemimpinan transformasional dengan variabel kinerja. Hal tersebut dibuktikan dengan nilai t hitung variabel Kepemimpinan Transformasional yaitu 2,421 dan lebih besar dari nilai t tabel sebesar 1,690 serta nilai signifikansinya $<0,05$ yaitu 0,022 . Variabel kinerja berpengaruh signifikan positif terhadap variabel 
kinerja dengan $\mathrm{t}$ hitung yaitu 3,035 dengan nilai t-hitung lebih besar dari t tabel yaitu 1,690 dan nilai signifikansinya 0,05 .

Tabel 2.

HASIL UJI REGRESI LINIER BERGANDA

\begin{tabular}{lcccccc}
\hline \multirow{2}{*}{ Variabel } & \multicolumn{2}{c}{ Determinasi $\left(\mathbf{R}^{2}\right)$} & Coefficient & \multicolumn{2}{c}{ Uji T } & \multicolumn{2}{c}{ Uji F } \\
\cline { 2 - 7 } & \multicolumn{1}{c}{ Adj. $\boldsymbol{R}$ Square } & B & $\boldsymbol{T}$ & Sig. & F & Sig. \\
\hline &, 497 & 13,676 & 4,046 &, 000 & &, 000 \\
(Constant) & &, 332 & 2,421 &, 022 & & \\
Kepemimpinan & &, 359 & 3,035 &, 005 & & \\
Transformasional & & & & & & \\
Otonomy Kerja & & & &
\end{tabular}

Sumber: Output SPSS PASW18 (Data diolah)

Koefisien jalur pada gambar 3 menunjukkan hubungan antara kepemimpinan transformasional terhadap kinerja atau P1 sebesar 0,332, hubungan antara kepemimpinan transformasional terhadap otonomi kerja atau P2 sebesar 0,659 sedangkan hubungan antara otonomi kerja terhadap kinerja atau P3 sebesar 0,359. Variance variabel otonomi kerja yang tidak dapat dideskripsikan oleh variabel kepemimpinan transformasional dan kinerja atau el adalah sebesar 0,823 dan variance variabel kinerja yang tidak dapat dijelaskan oleh kepemimpinan transformasional dan otonomi kerja atau e2 adalah sebesar 0.687. Kemudian berdasarkan hasil dari analisis jalur yang telah dilakukan, uji sobel digunakan untuk mengetahui apakah terdapat pengaruh mediasi atau tidak. Hasil hitung menunjukkan bahwa besaran thitung sebesar 2,9609 >1,6923 t tabel yang menunjukkan bahwa terdapat pengaruh mediasi antara tiga variabel yang diuji.

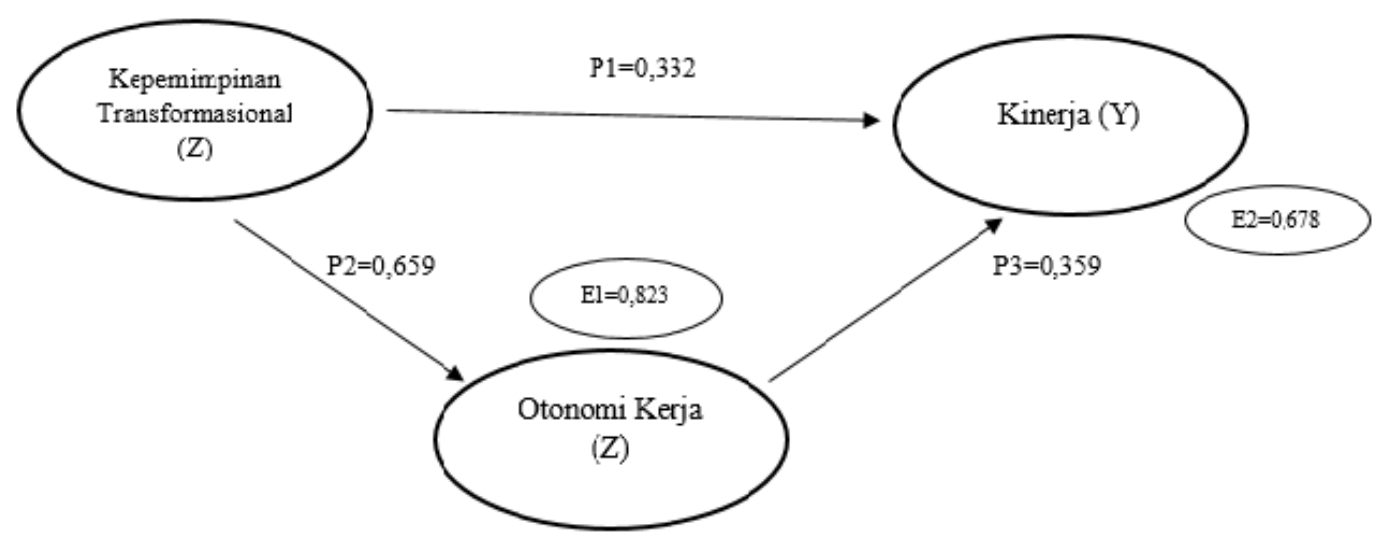

Sumber: Output SPSS (Data diolah)

Gambar 3. HASIL ANALISIS UJI JALUR

\section{Pengaruh Kepemimpinan Tranformasional terhadap Kinerja}

Hasil uji hipotesis yang telah dilakukan menunjukkan bahwa kepemimpinan transformasional dan kinerja memiliki hubungan positif signifikan. Siti (2017) menyatakan bahwa karyawan nyaman dan terbantu selama bekerja dengan keputusan pemimpin yang memilih untuk menerapkan gaya kepemimpinan transformasional. Kharisma pemimpin dalam organisasi sangat erat peranannya untuk membantu karyawan mendapat kepercayaan diri dan hal tersebut kemudian akan berpengaruh terhadap kualitas serta kuantitas kerja mereka. Randy et al. (2019) juga menyatakan kepemimpinan transformasional membawa pengaruh yang signifikan positif pada kinerja karyawan.

Hasil yang diperoleh dari pengujian, observasi serta wawancara yang dilakukan pada CV. SKM Indonesia menunjukkan bahwa penerapan kepemimpinan transformasional yang dilakukan dengan 
Muhammad Alief Ramadhani \& Nurul Indawati. Pengaruh Kepemimpinan Transformasional terhadap Kinerja Karyawan melalui Otonomi Kerja

cara melakukan dukungan, komunikasi verbal serta sikap pimpinan perusahaan mulai dari supervisor hingga HRD perusahaan yang proaktif memberikan support dan dorongan penuh pada karyawan untuk pengoptimalan kinerja karyawan selama metode kerja work from home berlangsung. Dijelaskan pula dari prespektif karyawan berdasarkan wawancara yang dilakukan bahwa mereka merasa terbantu dengan hadirnya pimpinan perusahaan ketika mereka mendapatkan kendala selama adaptasi kerja dari rumah. HRD menyebutkan hasil yang dihimpun pada website perusahaan selama beberapa bulan kebelakang menjelaskan bahwa kinerja karyawan dalam menyelesaikan project baik pada divisi 3D render visual maupun pengembangan website bisa dieksekusi karyawan dengan efektif dan tepat waktu meski pengerjaan dilakukan secara mandiri di rumah masing-masing. Perusahaan juga cukup baik dalam merespon keluhan serta keadaan yang ada di lapangan. Hal ini ditunjukkan dengan diciptakannya sebuah sistem yang mampu memantau kinerja harian karyawan secara rinci yang bisa diakses pada website perusahaan yang di dalamnya tersaji laporan kegiatan setiap karyawan, perencanaan kerja karyawan kedepan, hingga form absensi daftar hadir karyawan. Sistem ini cukup membantu kegiatan kerja baik dari sisi karyawan dan pimpinan ketika melakukan metode work from home . Lebih lanjut, wawancara dilakukan kepada karyawan dari divisi website development dan 3D rendering dan mendapati testimoni positif terkait peran pimpinan mulai dari HRD sampai supervisor yang berbagi peran dalam pemantauan kinerja mereka selama berada di rumah. Karyawan juga menuturkan bahwa metode kerja dari rumah ini memberikan mereka keleluasaan dalam menyelesaikan project yang sedang mereka kerjakan.

\section{Pengaruh Kepemimpinan Transformasional terhadap Otonomi Kerja}

Berdasar pada hasil uji hipotesis yang telah dilakukan, didapatkan hasil bahwa kepemimpinan transformasional memengaruhi otonomi kerja secara positif signifikan. Sesuai dengan pernyataan Jankelová et al. (2020) pengaruh positif muncul karena otonomi kerja mampu terbantu secara signifikan, sebab kepemimpinan transformasional mampu mendorong sikap optimis karyawan dalam memandang tujuan yang ada di masa depan. Dalam hubungan antara kepemimpinan transformasional terhadap kinerja argibisnis, otonomi kerja memiliki peranan positif sebagai variabel mediator. Otonomi kerja juga dapat berperan secara signifikan positif terhadap kepemimpinan transformasional dan berperan dalam menguatkan hubungan antar variabel (Gözükara \& Şimşek, 2015).

Berdasarkan pada hasil pengujian, observasi serta wawancara yang dilakukan pada CV. SKM Indonesia pula menunjukkan bahwa penerapan kepemimpinan transformasional diputuskan karena pimpinan perusahaan ingin secara maksimal melakukan dukungan terhadap metode WFH. Handayani et al. (2018) menyatakan otonomi kerja menawarkan kemungkinkan bagi karyawan untuk mendapatkan fleksibilitas dan kebebasan untuk mengatasi beban kerja seefisien mungkin, hingga dapat meminimalkan tekanan, konflik serta kelelahan. Kebebasan tersebut biasanya erat kaitannya dengan penjadwalan, pengembangan inisiatif, prosedur kerja dan kesempatan untuk turut andil kontribusi dalam proses pemilihan keputusan. Maka WFH diberlakukan oleh pimpinan di masa pandemi agar memudahkan karyawan dalam menuntaskan pekerjaannya dengan metode yang karyawan hendaki. Dikarenakan domisili karyawan yang mayoritas berada di luar daerah Surabaya menyebabkan opsi kerja di rumah merupakan keputusan paling bijak demi keberlangsungan perusahaan. Melalui pendapat dari karyawan pula didapati bahwa mayoritas dari mereka menyikapi secara positif terkait keseriusan pimpinan perusahaan dalam mendukung pola kerja baru mereka. Responsifitas pimpinan perusahaan yang tak jarang memberi bimbingan kepada mereka menjadi hal yang sering disebutkan ketika karyawan diberikan pertanyaan.

\section{Pengaruh Otonomi Kerja terhadap Kinerja Karyawan}

Hasil uji hipotesis menunjukkan adanya pengaruh signifikan positif dari otonomi kerja terhadap variabel kinerja. Hal ini juga sejalan dengan pernyataan Herwita \& Irma (2017) bahwa otonomi kerja memengaruhi kinerja karyawansecara signifikan positif. Karyawan yang memiliki kinerja yang tinggi akan cenderung memiliki kesetiaan dan rasa memiliki pada perusahaan yang tinggi sehingga mudah diberikan motivasi karena memiliki otonomi yang baik. Disebutkan pula bahwa secara konsisten otonomi kerja memiliki kontribusi terhadap peningkatan tanggung jawab dan kinerja karyawan. 
Berdasar pada hasil pengujian, observasi dan wawancara yang dilakukan pada CV. SKM Indonesia menunjukkan bahwa otonomi kerja yang dalam hal ini diwakilkan dengan pola kerja work from home yang dijalankan membuat karyawan mampu lebih leluasa untuk mengatur pola kerja paling efisien bagi mereka. Di sisi lain, perusahaan juga ingin menjaga kinerja karyawan tetap optimal dengan turun langsung membantu serta mengontrol dari jauh output kerja harian karyawan dengan menciptakan sebuah website untuk pelaporan tugas karyawan. Dari penuturan pimpinan dan karyawan didapatkan bahwa fleksibilitas yang didapat melalui pola kerja baru ini mampu dijalankan secara bertanggungjawab berkat sistem baru yang dibuat perusahaan tersebut.

\section{Pengaruh Kepemimpinan Transformasional terhadap Kinerja Melalui Otonomi Kerja}

Pengujian yang dilakukan menunjukkan hasil bahwa otonomi kerja memediasi hubungan antara kepemimpinan transformasional terhadap kinerja. Hal tersebut dibuktikan dengan penghitungan uji sobel yang memeroleh hasil bahwa thitung lebih besar daripada $t$ tabel. Hal ini sesuai dengan Randy et al. (2019) yang menyatakan pengaruh positif kepemimpinan transformasional terhadap kinerja karyawan, Gözükara \& Şimşek (2015) yang menyatakan bahwa kepemimpinan transformasional berpengaruh signifikan positif terhadap otonomi kerja serta Herwita \& Irma (2017) yang menyatakan bahwa otonomi berpengaruh signifikan positif terhadap otonomi kerja.

Sejalan dengan hasil pengujian, observasi dan wawancara yang dilakukan pada CV. SKM Indonesia wawancara karyawan selama melakukan kegiatan work from home mendapati fakta bahwa mereka merasa terbantu dengan hadirnya pimpinan perusahaan ketika mereka mendapatkan kendala selama adaptasi kerja dari rumah. HRD perusahaan menghimpun hasil dari website perusahaan selama beberapa bulan kebelakang kemudian diketahui bahwa kinerja karyawan dalam menyelesaikan project baik pada divisi 3D render visual maupun pengembangan website bisa dieksekusi karyawan dengan efektif dan tepat waktu meski pengerjaan dilakukan secara mandiri di rumah masing-masing.

\section{KESIMPULAN}

Dari pembahasan yang telah dijabarkan diperoleh hasil bahwa kepemimpinan transformasional berpengaruh secara positif signifikan terhadap kinerja karyawan CV. SKM Indonesia yang berarti bahwa semakin intens penerapan kepemimpinan transformasional maka akan berdampak pada semakin meningkatnya kinerja karyawan. Kepemimpinan transformasional juga didapati berpengaruh positif signifikan terhadap otonomi kerja karyawan CV. SKM Indonesia. Hal ini berarti bahwa semakin intens penerapan kepemimpinan transformasional maka kemampuan otonomi kerja karyawan akan semakin optimal. Otonomi kerja berpengaruh signifikan positif terhadap kinerja karyawan CV SKM Indonesia. Dengan kata lain semakin besar kemampuan otonomi kerja dari karyawan akan berpengaruh pada semakin meningkatkan kinerja mereka. Otonomi kerja mampu secara positif memediasi hubungan kepemimpinan transformasional dengan kinerja. Hal ini menunjukkan bahwa diterapkannya otonomi kerja dapat membantu kepemimpinan transformasional memeroleh pengaruh positif bagi kinerja karyawan CV. SKM Indonesia.

Hasil penelitian ini diharapkan mampu menjawab keraguan pimpinan perusahaan terkait penerapan sistem baru yang diterapkan dan menjadi rujukan serta masukan dalam upaya peningkatan kinerja karyawan. Hasil penelitian ini juga bisa digunakan untuk melihat bagaimana praktik kepemimpinan transformasional dan otonomi kerja yang terjadi pada karyawan CV. SKM Indonesia. Dapat pula digunakan sebagai rekomendasi untuk merancang strategi dalam menangani permasalahan perusahaan. Pada variabel kepemimpinan transformasional, hadirnya pimpinan secara langsung pada setiap kendala yang dihadapi karyawan selama pengerjaan project dapat dikembangkan dengan melakukan evaluasi rutin yang mencakup aspirasi, kritik dan saran, utamanya dari karyawan terhadap manajer tingkat atas yang bersinggungan dengan bidang kerja karyawan. Evaluasi ini nantinya bisa digunakan untuk lebih meningkatkan sinergi antara pimpinan dan karyawan dalam pengoptimalan kinerja perusahaan. Untuk otonomi kerja, perusahaan disarankan untuk terus melakukan pengembangan pada sistem baru berupa website yang dibuat perusahaan, karena inovasi tersebut dirasa karyawan efektif untuk memudahkan mereka menyesuaikan pola kerja mereka selama periode 
Muhammad Alief Ramadhani \& Nurul Indawati. Pengaruh Kepemimpinan Transformasional terhadap Kinerja Karyawan melalui Otonomi Kerja

work from home ini. Pengembangan ini disarankan untuk terus dilakukan demi menjaga iklim kerja perusahaan serta menciptakan otonomi kerja yang lebih baik dan kinerja yang optimal pada karyawan.

Penelitian ini memiliki batasan pada cakupan populasi penelitian yang rendah. Disarankan pula selanjutnya untuk mengambil objek perusahaan yang lebih besar atau berasal dari bidang yang berbeda dengan jumlah responden yang lebih banyak. Selain itu terdapat batasan di mana penelitian ini hanya mengambil responden pada pegawai tetap perusahaan dan tidak mengambil responden karyawan yang bekerja secara rekanan atau by project only yang dimiliki perusahaan.

\section{DAFTAR PUSTAKA}

Alshamsi, S., Isaac, O., Ameen, A., Nusari, M., \& Bhumik, A. (2020). The Moderating Effect of Job Autonomy on the Relationship between Transformational Leadership and Organizational Innovation. Test Engineering and Management, 82(2), 14795-14810.

Aprilia, A. E., \& Prasetyo, A. R. (2019). Hubungan Antara Otonomi Kerja (Work Autonomy) dengan Kebahagiaan Kerja (Happiness At Work) pada Pengrajin Kain Batik Tulis di Paguyuban Giriloyo Yogyakarta. Empati, 8(2), 139-146.

Aqmarina, N., Utami, H., \& Prasetya, A. (2016). Pengaruh Kepemimpinan Transformasional dan Transaksional terhadap Kepuasan Kerja dan Kinerja Karyawan (Studi Pada Karyawan Hotel Gajahmada Graha Malang). Jurnal Administrasi Bisnis S1 Universitas Brawijaya, 35(2), 164173.

Ardy, L. P., \& Fajrianthi, F. (2019). Job Autonomy sebagai Moderator pada Pengaruh Job Insecurity terhadap Perilaku Kerja Inovatif. Jurnal Psikologi Teori Dan Terapan, 9(2), 101. https://doi.org/10.26740/jptt.v9n2.p101-111

Asbari, M., Dewiana Novitasari, G., Silitonga, N., \& Pebrina, E. T. (2020). Analisis Pengaruh Efektivitas Kepemimpinan Transformasional dan Kesiapan untuk Berubah terhadap Kinerja Karyawan Wanita di Masa Pandemi Covid-19. Jurnal Ilmiah Mahasiswa Ekonomi Manajemen, 18(2), 615-632. http://www.jim.unsyiah.ac.id/EKM/article/view/15502

Bass, B. M., \& Avolio, B. J. (1990). The Implications of Transactional and Transformational Leadership for Individual, Team, Organizational Development. Research in Organizational Change and Development, 4, 231-272.

Cahyandani, P. T. (2021). Pengaruh Kepemimpinan Transformasional dan Employee Engagement Terhadap Kinerja Karyawan PT. Taspen (Persero) Kantor Cabang Utama Surabaya. Jurnal Ilmu Manajemen, 9(1), 1-11. https://journal.unesa.ac.id/index.php/jim/article/view/9745

Diab-Bahman, R., \& Al-Enzi, A. (2020). The Impact of COVID-19 Pandemic on Conventional Work Settings. International Journal of Sociology and Social Policy, 40(9-10), 909-927. https://doi.org/10.1108/IJSSP-07-2020-0262

Gözükara, İ., \& Şimşek, O. F. (2015). Linking Transformational Leadership to Work Engagement and the Mediator Effect of Job Autonomy: A Study in a Turkish Private Non-Profit University. Procedia - Social and Behavioral Sciences, 195, 963-971. https://doi.org/10.1016/j.sbspro.2015.06.274

Handayani, A., Maulia, D., Dian M, M. A. P., \& Nyoman M, N. A. (2018). Pengaruh Otonomi Kerja terhadap Keseimbangan Kerja-Keluarga dengan Komitmen Peran sebagai Variabel Pemediasi. Seurune Jurnal Psikologi Unsyiah, 1(1), 53-73. https://doi.org/10.24815/s-jpu.vli1.9924

Hartono, A., \& Rahadi, D. R. (2021). Work From Home terhadap Kinerja Karyawan pada Masa 
Pandemi Covid 19. Jurnal Manajemen Bisnis, 18(1), 16-21. https://doi.org/10.38043/jmb.v18i1.2728

Herwita, \& Irma, A. (2017). Pengaruh Otonomi terhadap Kinerja Pegawai dengan Kejelasan Tujuan Organisasi sebagai Pemediasi pada PT. PLN (persero) Wilayah Aceh. Jurnal Ilmiah Mahasiswa Ekonomi Manajemen, 3(3), 59-72.

Huda, S., \& Bahri, S. (2017). Pengaruh Otonomi Kerja terhadap Locus Of Control dengan Kepuasan Kerja sebagai Pemediasi (Pada Kantor Dinas Pendidikan Provinsi Aceh ). Jurnal Ilmiah Mahasiswa Ekonomi Manajemen, 1(3), 195-212.

Jankelová, N., Joniaková, Z., Némethová, I., \& Blštáková, J. (2020). How to Support The Effect of Transformational Leadership on Performance in Agricultural Enterprises. Sustainability (Switzerland), 12(18), 1-17. https://doi.org/10.3390/su12187510

Karimikia, H., \& Joseph, D. (2019). Negative Outcomes of ICT Use at Work: Meta-analytic Evidence and The Role of Job Autonomy. Internet Research, 31(1), 159-190. https://doi.org/10.1108/INTR-09-2019-0385

Muecke, S. (2019). How Does Job Autonomy Influence Job Performance? a Meta-Analitic Test of Theoritical Mechanisms. Academy of Management, 1 .

Nazwirman. (2019). Analysis of Employee Performance: A Case Study in Port Corporation. Jurnal Organisasi dan Manajemen, 15(1), 24-35. https://doi.org/10.33830/jom.v15i1.7.2019

Nurdin, S., \& Rohendi, A. (2016). Gaya Kepemimpinan Transformasional, Budaya Organisasi, dan Kinerja Karyawan dengan Mediasi Komitmen Organisasi. Ecodemica, 4(1), 86-100.

Nurhuda, A., Sardjono, S., \& Purnamasari, W. (2019). Pengaruh Gaya Kepemimpinan Transformasional, Disiplin Kerja, Lingkungan Kerja terhadap Motivasi dan Kinerja Karyawan Rumah Sakit Anwar Medika Jl. Raya Bypass Krian Km. 33 Balongbendo - Sidoarjo. Ekonomi Manajemen, 1(1), 1-7.

Randy, M., Agung, S., \& Kuraesin, E. (2019). Pengaruh Kepemimpinan Transformasional dan Motivasi Kerja terhadap Kinerja Karyawan. Manager: Jurnal Ilmu Manajemen, 2(2), 69. https://doi.org/10.32832/manager.v2i2.2562

Rulysca, P. A. (2020). Determinasi Lingkungan Kerja dan Komitmen Organisasi terhadap Kinerja Karyawan PT. Sinar Niaga Sejahtera Sidoarjo. Jurnal Ilmu Manajemen, 8(2015), 1383-1393. https://journal.unesa.ac.id/index.php/jim/article/view/9656

Sari, R. N. I., \& Hadijah, H. S. (2016). Peningkatan Kinerja Pegawai melalui Kepuasan Kerja dan Disiplin Kerja. Jurnal Pendidikan Manajemen Perkantoran, 1(1), 204. https://doi.org/10.17509/jpm.v1i1.3389

Septyan, F. B., Musadieq, M. Al, Mukzam, M. D., Administrasi, F. I., \& Brawijaya, U. (2017). Pengaruh Gaya Kepemimpinan Transformasional terhadap Motivasi dan Kinerja (Studi pada Karyawan CV. Jade Indopratama Malang). Jurnal Administrasi Bisnis (JAB), 53(1), 81-88.

Setiawan, K. C. (2015). Pengaruh Motivasi Kerja terhadap Kinerja Karyawan Level Pelaksana di Divisi Operasi PT. PUSRI PALEMBANG. Jurnal Psikologi Islami, 1(2), 43-53.

Siswatiningsih, I., Raharjo, K., \& Prasetya, A. (2019). Pengaruh Kepemimpinan Transformasional dan Transaksional terhadap Budaya Organisasi, Motivasi Kerja, Komitmen Oganisasional dan Kinerja Karyawan. Jurnal Bisnis Dan Manajemen, 5(2), 146-157. 
Muhammad Alief Ramadhani \& Nurul Indawati. Pengaruh Kepemimpinan Transformasional terhadap Kinerja Karyawan melalui Otonomi Kerja

https://doi.org/10.26905/jbm.v5i2.2388

Siti, D. N. (2017). Pengaruh Kepemimpinan Transformasional terhadap Kinerja Pegawai (Studi Kasus di Dinas Penanaman Modal dan Pelayanan Perizinan terpadu Satu Pintu Sei Rampah). Jurnal Pendidikan Manajemen Perkantoran, 1(1), 13-14. https://doi.org/10.17509/jpm.v1i1.3389

SKM Indonesia. (2018). Tentang kami: SKM Indonesia. SKMI.Web.Id. https://www.skmi.web.id/tentang-kami.html

Widyawati, J. R. (2021). Pengaruh Faktor Pendidikan dan Gaya Kepemimpinan Transformasional terhadap Kinerja Karyawan melalui Motivasi Kerja di PT. PLN UIT JBTB UPT Surabaya. Jurnal Ilmu Manajemen (JIM), 9(1), 154-166.

Yoshi, T. (2017). Motivasi Kerja terhadap Kinerja Karyawan pada PT . Premier Management Consulting. Agora, 5(1). 